\title{
RETAIL GOLD INDUSTRY - GLITTERING FUTURE
}

\author{
*Prof. Geevaratna
}

\begin{abstract}
Au, Atomic number 79, An object of worship, Gold. Gold is forever beautiful, useful, and never wears out. Gold has a universal appeal and is worshipped in all climates, without a single temple, and by all classes, without a single hypocrite. The reason may be it is the only metal that combines lustrous beauty, easy workability, rarity and virtual indestructibility. No other commodity enjoys as much universal acceptability and marketability as gold. Gold has always been considered a sacred item by Hindus and is a must for religious functions. Jewellery industry is one such area which lags behind and not being marketing savvy. There is lack of marketing activities from jewellery companies. The gold jewellers in India operate within more rigidly defined parameters both in terms of product sourcing and sales. Today all that has changed. A far more aggressive, but a well-defined, strategic marketing policy for creating brand awareness is the need of the hour. The Indian jewellery consumer is getting more \& more trend conscious. This paper attempts to analyze growth and the changing trends of gold industry in future.
\end{abstract}

\section{Introduction}

Au, Atomic number 79, An object of worship, Gold. Gold is forever beautiful, useful, and never wears out. Gold has a universal appeal and is worshipped in all climates, without a single temple, and by all classes, without a single hypocrite. The reason may be it is the only metal that combines lustrous beauty, easy workability, rarity and virtual indestructibility. No other commodity enjoys as much universal acceptability and marketability as gold. Gold has always been considered a sacred item by Hindus and is a must for religious functions. Indians attribute gold with Agni as Hiranyakt, "Gold maker", Brahma as Hiranyagarbha, "born from Gold" , traditionally given as "streedhan" to the woman at the time of marriage, in the form of jewellery which remains as an asset that is tnuiy hers forever. Jewellery for Indian woman is not only for festivals, also for work and other casual occasions. Of-late it is being introduced in make-up and cosmetics.

\section{History and Growth}

Gold ornaments were discovered during Harappa and Mohanjodaro civilisations, i.e., thousands of years before Christ ( $\mathrm{BC}$ ). The earliest gold jewellery dates from the Sumer civilisation in between the Tigris and Euphrates rivers in southern Iraq around 3000 BC. In Egypt, gold jewellery and other artifacts have been found in Pharoah's tombs dating to around $1500 \mathrm{BC}$. The first pure gold coins were struck by King Croesus of Lydia (present-day Turkey) during his reign between 560 and $547 \mathrm{BC}$ and gold coins have continued as legal tender since that time.

The forms of jewellery used in the ancient period are quite different from what we use today. Designs were inspired by forms of nature like flowers, animals, birds, gods, holy symbols etc., Head ornaments highlighted the Indian culture since ages. Turban jewellery was considered as an

* MBA, MS (Psychology), M.Phil. (Ph.D), Faculty, M.S. Ramaiah College of Arts, Commerce and Science, Bangalore. 
important part of jewellery for the rulers. The historical India has provided various explanations about the different dynasties that have come and gone and have left their mark on the Indian soil. The turban jewellery helps to trace many of historical things, as fine artwork of jewellery was choice of every particular king.

\section{Jewellery 4 -C's}

Jewellery is one of the oldest forms of body adornment, and the first pieces of jewellery were made from natural materials such as animal teeth, shell, wood and carved stone. 'Jewellery' is literally any piece of fine material that someone uses to adorn themselves. Derived from the word jewel, which was anglicized / in English idiom from the old French "Jouel" in around the 13th century. In Old English gelo, stands for yellow. It can be made out of almost every substance known to man and has been made to decorate nearly every body part, from hairpins to toe rings.

4-C's which Determine the quality of Gold

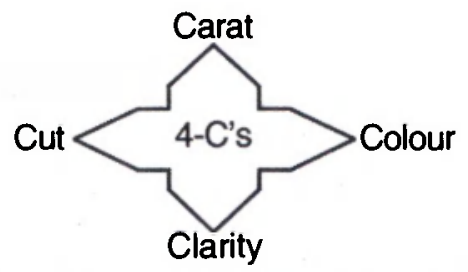

Content of Gold Measurable : Karat Percent Gold

$24 \mathrm{Kt}$

$100 \%$ Gold

$18 \mathrm{Kt}$

$75 \%$ Gold

$14 \mathrm{Kt}$

$58.3 \%$ Gold

$10 \mathrm{Kt}$

$41.7 \%$ Gold

Colour Palette of Gold / Gold Composition

Coloured Gold Alloy Metal (S) Added To The Gold

Yellow Gold $50 \%$ Silver \& $50 \%$ Copper

White Gold Nickel, Zinc, Copper, Tin \& Manganese

Pink (Rose) Gold $75 \%$ Gold , $16 \%$ Copper \& $9 \%$ Silver

Green Gold $75 \%$ Gold \& $25 \%$ Silver Or Cadium

Blue Gold $75 \%$ Gold \& Some Indium And Gallium

Grey Gold $80 \%$ Gold \& $15-20 \%$ Iron

Red Gold 75\% Gold, $20.5 \%$ Copper, $4.5 \%$ Silver

\section{Gold - The Global Demand, Supply and} Consumption

\section{Increasing recent mine production does not meet consumption}

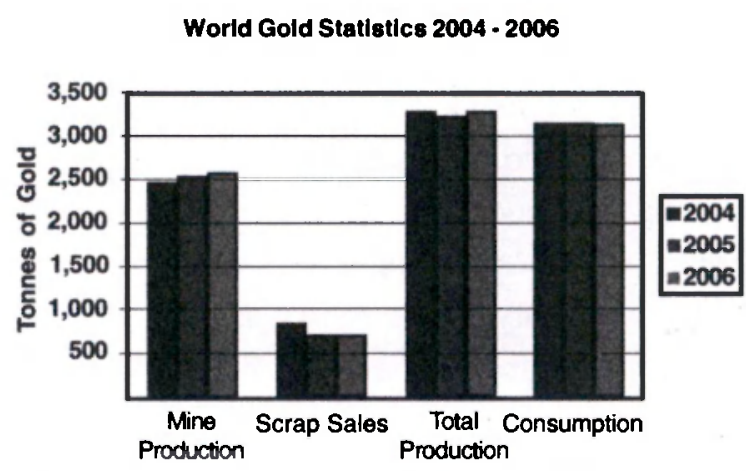

The global market for Gold is estimated at 3300 tonnes. South Africa is the world's largest producer of gold, while India is the largest consumer. Major demand for gold comes from jewellery sector.

chart 1 gives a clear idea of mine production of Gold, scrap sales and Consumption. Apart from jewellery the other demand for gold comes from retail investment - i.e. from gold's use as a private reserve asset. The amount used in industry, e.g. in electronics and dental surgery.

Gold Demand ( Volume and Value) and Gold Price (Rupees )

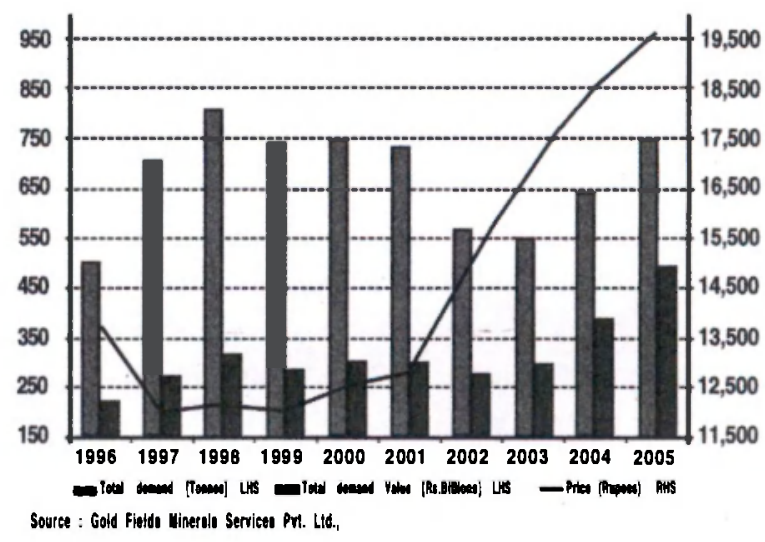

Chart 2 The above Chart 2 gives gold demand both in terms of tonnes and value in Rupees between 1996 to 2005 . 
Figure 1 : Annual Demand' for Gold (tonnas) 10 year average, $1996 \cdot 2005$

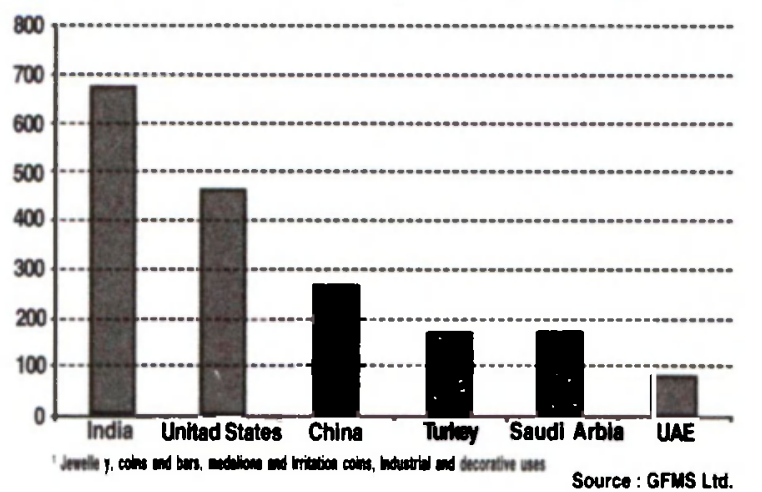

Chart 3 - It is estimated as of now India holds nearly 14,000 tonnes of gold accounting for $9 \%$ of the world's cumulative production of around 153,000 tonnes. Indians consume more gold than any other nation - 850 tonnes a year - and the market is growing at 20 per cent per year. India is currently accounting for around 22 per cent of the world's gold production in terms of jewellery. The world's largest consumer of gold jewellery, India annually imports around 880 tonnes of the precious metal, much of which is used in jewellery production. Indian consumers are well known for their consumption of the precious metal gold and prefer it to be pure, rather than mixed with other metals such as platinum and silver.

\section{Trends in Gold Jewellery Market}

Over the years, global markets have been impacted by several developments but currently the trends in the global gold jewellery market are:

- Increased competition among the top producing countries.

- Emergence of different materials different alloys within gold as well as non-gold jewellery.

- Emergence of new manufacturing techniques

- Requirement of stricter quality norms and hallmarking
Demand for branded jewellery in India growing at the rate of $20 \%$ annually because of acceptance of branded jewellery by younger generation ie., $54 \%$ of the population is in the age group 16 to 35 .

Gold jewellery saw a 37 per cent rise during April 2006 - Feb 2007 as many festivals fall in between. Akshaya Tritiya - April, Diwali, Karva Chauth October, Dussera, Varamahalakshmi - September, Onam - Kerala, Pongal - Tamilnadu - January.

Spending on gold has hit a record high this year in spite of rising prices pushing the demand for gold jewellery. Women have been the major target segment for Gold Jewellery in spite it being wom by other Gender.

\section{Importance of Gold for an Economy}

December 1990, The foreign exchange situation was causing anxiety. It was a very critical period for Indian economy as the country was struggling with less than $\$ 1$ billion in reserves, and a much higher shortterm debt. The root-cause of the 1991 crisis was a sudden lack of liquidity. India's own political situation was messy. International rating agencies had also lowered India's credit rating.

Now it has been a time for celebration on the BoP front as $\mathrm{RBI}$ recently reported that it has reached a level of forex reserves of $\$ 100$ billion. This figure is magical, especially considering that with a decade back.

\footnotetext{
Present Scenario of Gold Jewellery Industry

In India jewellery is crafted not only for humans but also for Gods and Goddess ( kavachas, omaments, chatri's ). Different regions of India have unique jewellery making style. Design innovations through collections is inspired from various jewellery traditions. In India chettinad, rajputana, tajmahal, mughal, temple, tarkashi, minakari, kundan, thewa, nakkashi, etc., has been
} 
Gold price, Rupees per ounce, London pm fix

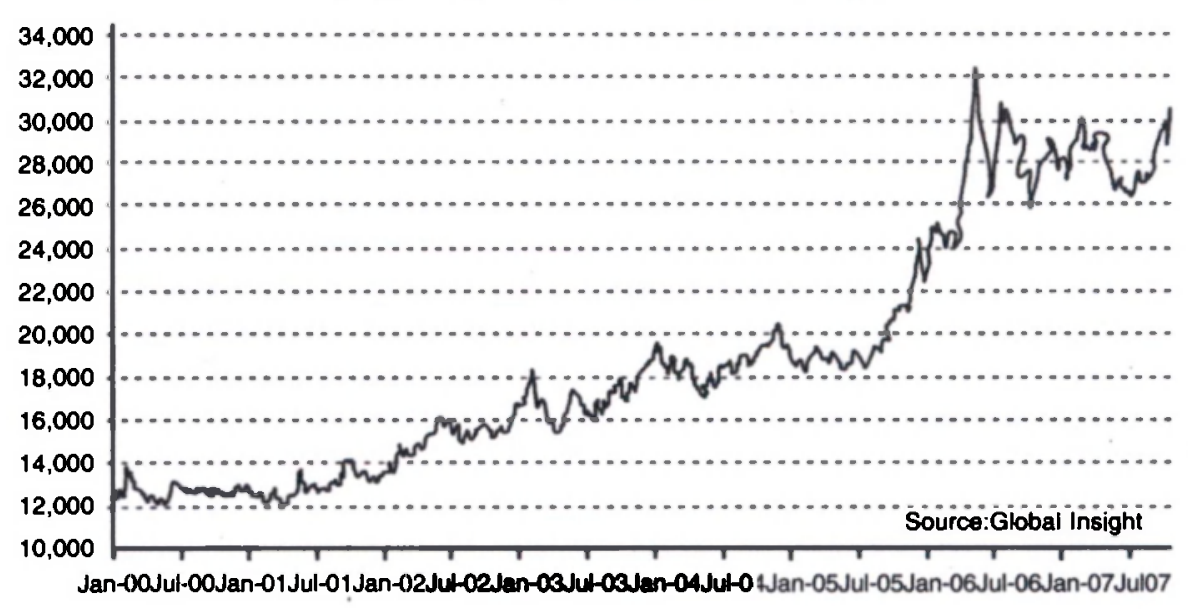

explored to a greater extent. Ancient inspirations are now crafted with modern technology in new forms with different brand names by different manufacturers / companies. Pendants and necklaces have been an epic chapter in the history if Indian jewellery.
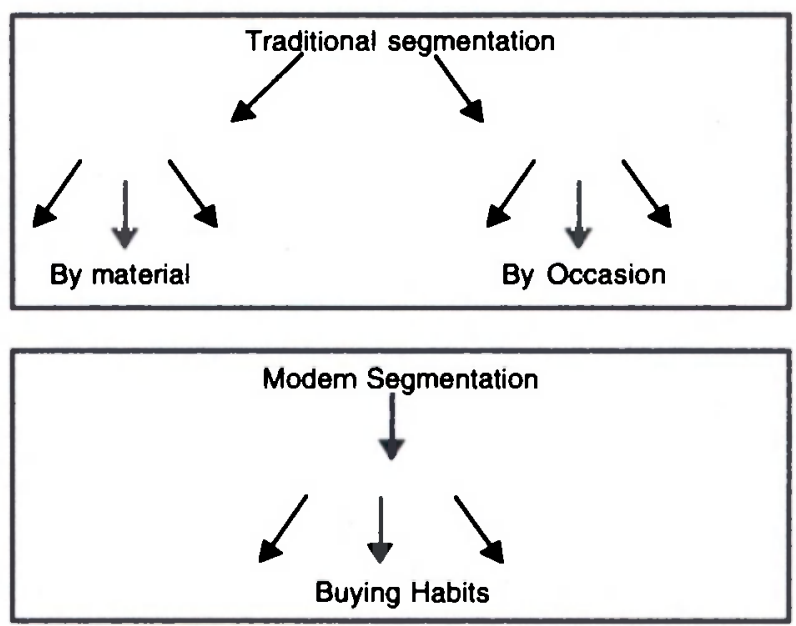

Everyday wear / Daily wear : also called 9-5 wear mostly.

\section{Gold - The future is glittering}

Gone are the days when goldsmiths ruled the roost. Though they do still cater to a large section of society, there has been a paradigm shift in the profession over the years. Today across India there are more than 7000 retail outlets. Retail Jewellery is growing at a faster rate. The sales of branded gold jewellery were Rs 435 Billion in 2000 which has grown beyond

1 India retail report 2005.
Rs 3600 Billion by 2006 . With approximately 10 million marriages happening in the country every year, organized retailing' ${ }^{1}$ is projected to grow at the rate of 25 percent - 30 percent p.a and is estimated to reach over an astounding $R s$, $1,00,000$ crores ( 1 trillion ) by 2010 . 
According to unity Marketing's Luxury Report 2006, which was based on the aggregate results of 25plus global luxury marketers includes luxury purchases in the four luxury categories - home luxuries, personal luxuries (including jewellery), automobiles and luxury experiences (such as travel and entertainment). It is estimated that the sale of gold will raise Rs 315 billion by the year 2010, from their present level of Rs 175 billion. By the year 2015 , revenues are predicted to reach Rs 479 billion. About 37 new brands have been launched in the last couple of years alone in India! Viz., International brands like Cartier, Tiffany etc.,. India being the world's largest consumer of Gold, this study gets an added significance in present context. This paper gives an insight about jewellery customers, their buying styles, factors considered while purchasing gold, behaviours and attitudes.

\section{Some interesting Facts and figures ;}

- India has approximately 5 million luxury consumers.

- Over $60 \%$ of the population is under 35 years.

- Over $18 \%$ of the India's population falls in the top-tier socio-economic class, which is a huge potential market for luxury goods brands.

\section{India - A FACTUAL BACKGROUND}

India is not only the world's largest gold consuming market but also the world's third largest diamond market. The Indian gems and jewellery is extremely fragmented with $97 \%$ operating as independent jewellers and the branded segment being a meager $3 \%$ and hence there is lots of scope for growth of branded gold retailing.

\section{South India}

South India is the largest and biggest market for gold and gold jewellery in India. The South India market accounts for more than 45 per cent of the total gold demand in India.

\section{Bangalore}

With rise of new industries, and the software boom over the last decade, Bangalore has emerged as a cosmopolitan centre and there is a new generation of consumers with an entirely different mindset. In a sense, the new generation is a perfect mix of old values and new trends. Therefore the demand for traditional heavy jewellery is accompanied by sophisticated delicate machine made jewellery.

Apart from developing a new positioning and brand expression for Gold, the work of advertising, PR and media agencies also needed co-ordinating. Promotional events and conferences, PR activity, exhibitions and trade fairs are all playing a vital role in expressing the Gold brand consistently worldwide

Major Brand Players :

$\begin{array}{llll}\text { - } & \text { Asmi } & \bullet & \text { Eros } \\ \text { - } & \text { Tanisha } & \bullet & \text { Signature } \\ \text { - } & \text { Kiah } & \bullet & \text { Solitaire } \\ \text { - } & \text { Nakshatra } & \bullet & \text { Gill } \\ \text { - } & \text { Aurra } & \bullet & \text { Agni } \\ \text { - } & \text { D'damas } & \bullet & \text { Orra }\end{array}$

\section{OBJECTIVES}

The objective of the study are:

1. To examine the history, growth, development and trends of gold jewellery.

2. To find the factors influencing their purchasing patterns and brand communication.

3. To understand the Role of technology in selecting a brand.

4. To discover the latest innovations and developments in the world jewellery market 


\section{Limitations of the Study}

The limitations of this study are:

1. Data was collected during the four day event at Jewels of India Exhibition, Sree Kanteerva Stadium, Bangalore.

2. Sample size being 500 restricted to women only. Bangalore being a vast spread city, the sample size may fail to represent the entire Bangalore city.

\section{Methodology}

Primary data collection was done through a convenient questionnaire for 500 respondents at Jewels of India, Sree Kanteerva Stadium, Bangalore.

Secondary data Source: Joumals ,Bulletins, Books, Websites, Previous Research works

Statistical Tool for Data Analysis : The interpretation of the data is made using simple percentage, tabulation. Various Graphs and Charts are depicted understand the data easily. MS- Excel was used as a main Software Tool for data tabulation and calculation.

Data Analysis : ( 'Source of data for Table 1 Table 10 is Primary Data )

TABLE 1 : OCCUPATION OF THE RESPONDENTS

\begin{tabular}{|l|c|c|}
\hline OCCUPATION & $\begin{array}{c}\text { NO. OF } \\
\text { RESPONDENTS }\end{array}$ & $\%$ \\
\hline Business & 170 & 34 \\
\hline Profession & 65 & 13 \\
\hline Service & 75 & 15 \\
\hline Employee & 70 & 14 \\
\hline Students & 50 & 10 \\
\hline Housewives & 35 & 7 \\
\hline Designer & 5 & 1 \\
\hline Not Given & 30 & 6 \\
\hline Total & 500 & 100 \\
\hline
\end{tabular}

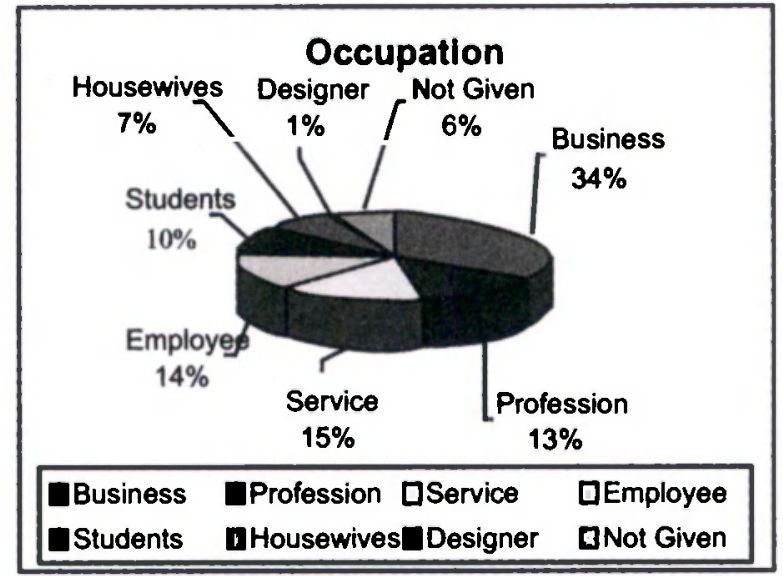

It is inferred from the above table 1 that $34 \%$ of the 500 respondents occupation was business, followed by $13 \%$ from service sector.

TABLE 2 : Sources of Information through different Media

\begin{tabular}{|l|c|l|}
\hline $\begin{array}{l}\text { SOURCE OF } \\
\text { INFORMATION }\end{array}$ & $\begin{array}{c}\text { NO. OF } \\
\text { RESPONDENTS }\end{array}$ & $\%$ \\
\hline TV & 25 & 5 \\
\hline NEWSPAPER & 285 & 57 \\
\hline RADIO & 0 & 0 \\
\hline HOARDINGS & 55 & 11 \\
\hline NOT GIVEN & 90 & 18 \\
\hline INVITATION & 45 & 9 \\
\hline Total & 500 & 100 \\
\hline
\end{tabular}

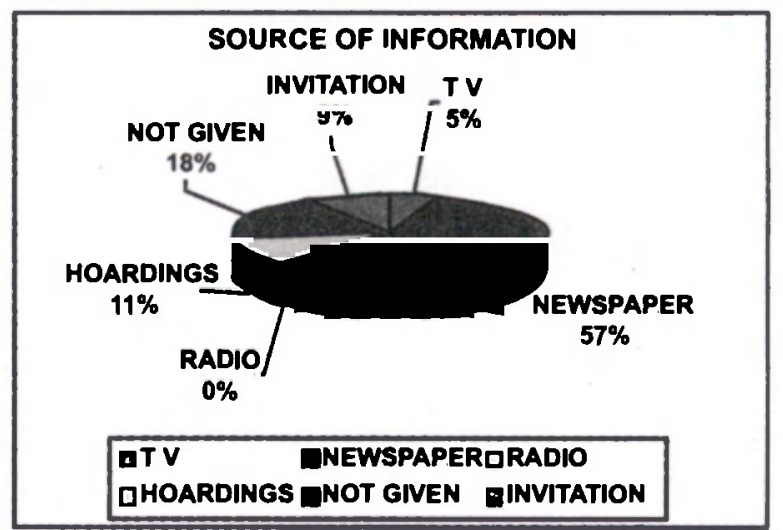

It is clear that the major source of information to the respondents was Newspaper with $57 \%$. 
TABLE 3: People accompanying theRespondents

\begin{tabular}{|l|c|l|}
\hline ACCOMPANISHIP & $\begin{array}{c}\text { NO. OF } \\
\text { RESPONDENTS }\end{array}$ & $\%$ \\
\hline FAIMILY & 415 & 83 \\
\hline COLLEAGUES & 10 & 2 \\
\hline FRIENDS & 50 & 10 \\
\hline ALONE & 25 & 5 \\
\hline Total & 500 & 100 \\
\hline
\end{tabular}

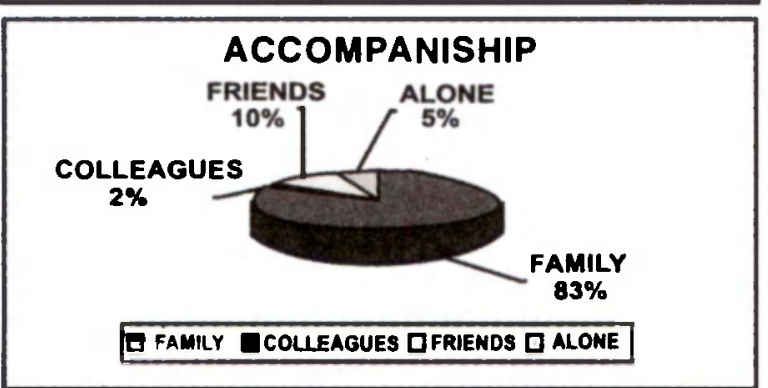

It is inferred from the above table that majority of the respondents accompanied their family members for purchasing Gold jewellery whereas very few prefer to go with their colleagues or alone.

TABLE 4 : Purpose of Purchasing Gold Jewellery

\begin{tabular}{|l|c|l|}
\hline $\begin{array}{l}\text { PURPOSE OF } \\
\text { PURCHASE }\end{array}$ & $\begin{array}{c}\text { NO. OF } \\
\text { RESPONDENTS }\end{array}$ & $\%$ \\
\hline INVESTMENT & 305 & 61 \\
\hline AESTHETIC & 185 & 37 \\
\hline OTHERS & 10 & 2 \\
\hline TOTAL & 500 & 100 \\
\hline
\end{tabular}

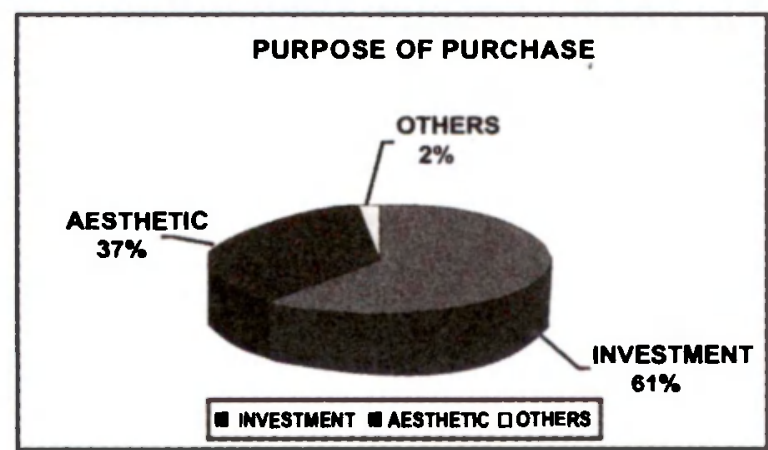

It is inferred from the above table that majority of the respondents ie., $61 \%$ consider gold as an investment rather as a thing of beauty.
TABLE 5 : Factors influening the purchase of gold jewellery

\begin{tabular}{|l|c|}
\hline $\begin{array}{l}\text { FACTORS } \\
\text { INFLUENCING }\end{array}$ & $\begin{array}{l}\text { NO. OF } \\
\text { RESPONDENTS }\end{array}$ \\
\hline DESIGN & 370 \\
\hline CHOICE & 60 \\
\hline BRAND NAME & 90 \\
\hline $\begin{array}{l}\text { GUARANTEE ON } \\
\text { CONTENT }\end{array}$ & 210 \\
\hline
\end{tabular}

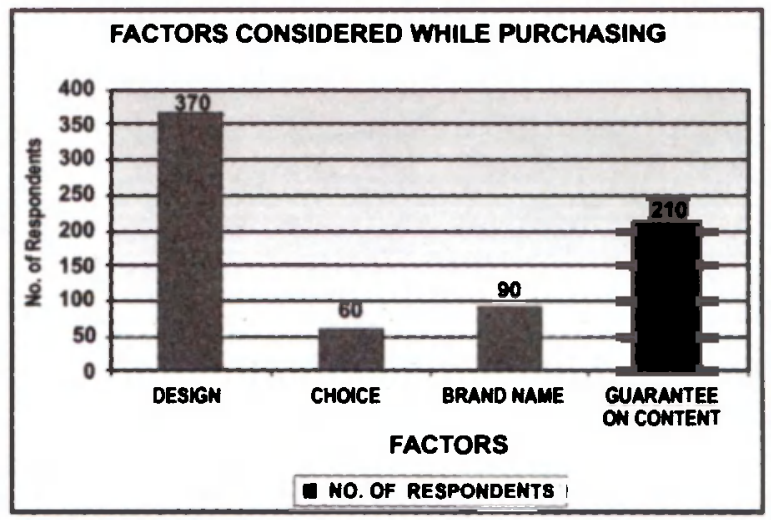

It is inferred from the above table that majority of respondents $i$ e., 370 out of 500 look for designs when selecting gold jewellery.

TABLE 6 : Respondents opinion about Gold Market

\begin{tabular}{|l|l|l|}
\hline $\begin{array}{l}\text { MARKET } \\
\text { BOOMING } \\
\text { FOR GOLD }\end{array}$ & $\begin{array}{l}\text { NO. OF } \\
\text { RESPONDENTS }\end{array}$ & $\%$ \\
\hline YES & 490 & 98 \\
\hline NO & 10 & 2 \\
\hline Total & 500 & 100 \\
\hline
\end{tabular}

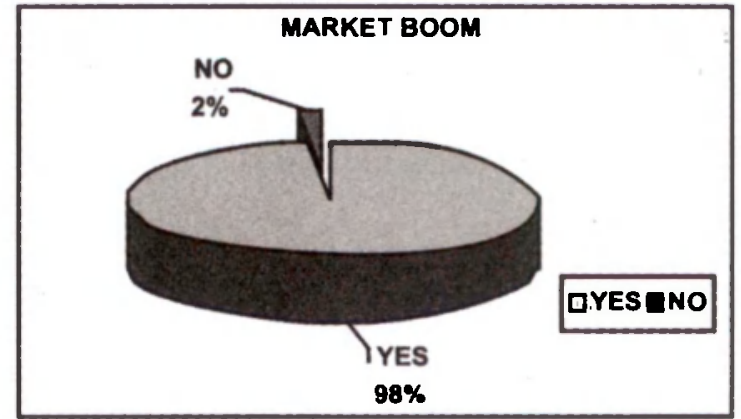

It is inferred from the above table that majority of respondents ie., $98 \%$ out of 500 believe gold market is booming and hence invest on gold. 
TABLE 7: Respondents liking towards Foreign Designs

\begin{tabular}{|l|c|l|}
\hline $\begin{array}{l}\text { LIKING FOR } \\
\text { FOREIGN } \\
\text { DESIGNS }\end{array}$ & $\begin{array}{l}\text { NO. OF } \\
\text { RESPONDENTS }\end{array}$ & $\%$ \\
\hline YES & 355 & 71 \\
\hline NO & 110 & 22 \\
\hline NO ANSWER & 35 & 7 \\
\hline Total & 500 & 100 \\
\hline
\end{tabular}

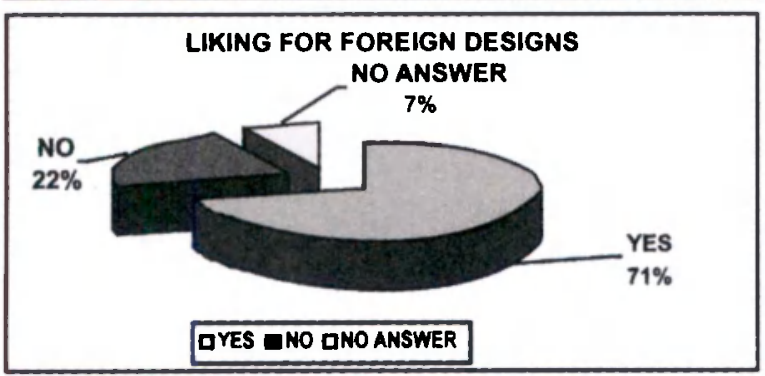

It is inferred from the above table that 355 respondents out of 500 ie., $71 \%$ like foreign designs.

TABLE 8: Reasons for Preferring Gold

\begin{tabular}{|l|c|}
\hline $\begin{array}{l}\text { REASONS FOR } \\
\text { PREFERRING GOLD }\end{array}$ & $\begin{array}{l}\text { NO. OF } \\
\text { RESPONDENTS }\end{array}$ \\
\hline DAILY WEAR & 190 \\
\hline STATUS SYMBOL & 90 \\
\hline USEFUL IN EMERGENCY & 10 \\
\hline OCCASIONS & 255 \\
\hline LOVE OF JEWELLERY & 85 \\
\hline
\end{tabular}

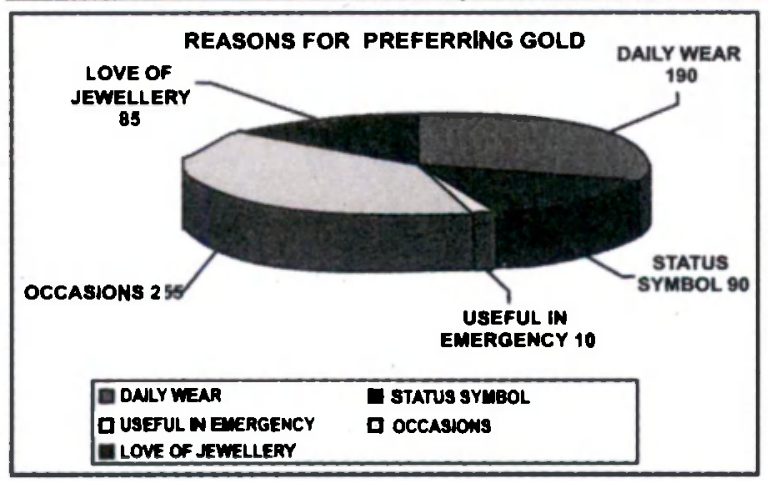

It is inferred from the above table that 255 respondents out of 500 prefer gold for occasions, followed by 190 respondents preferring gold jewellery for daily wear.
TABLE 9 :

\begin{tabular}{|l|c|}
\hline $\begin{array}{l}\text { ARTICLE } \\
\text { PREFERRED }\end{array}$ & $\begin{array}{c}\text { NO. OF } \\
\text { RESPONDENTS }\end{array}$ \\
\hline NECKLACE & 320 \\
\hline CHAIN & 115 \\
\hline BANGLES & 145 \\
\hline EARRINGS & 195 \\
\hline FINGERRINGS & 95 \\
\hline PENDANTS & 170 \\
\hline FULLSETS & 40 \\
\hline OTHERS & 55 \\
\hline
\end{tabular}

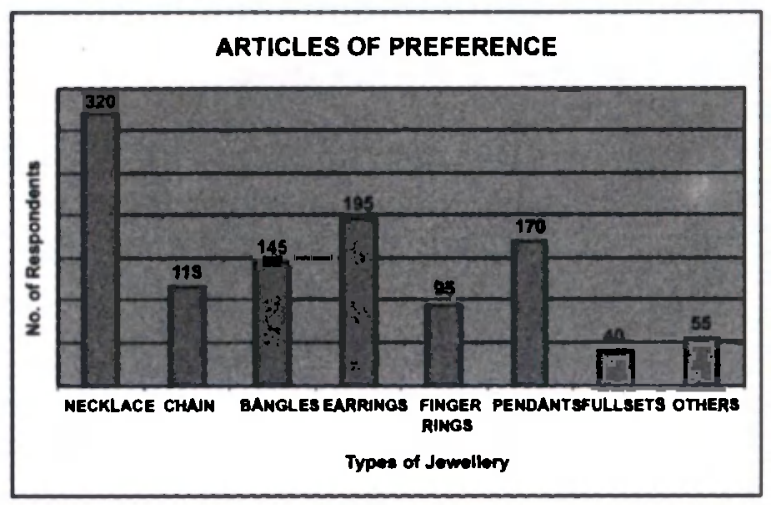

It is inferred that neck pieces were dominating over other articles with 320 out of 500 respondents preferring necklaces, while very few preferred full sets.

TABLE 10 : Combination of Metal Preferred

\begin{tabular}{|l|c|c|}
\hline $\begin{array}{l}\text { COMBINATION } \\
\text { OF METALS }\end{array}$ & $\begin{array}{l}\text { NO. OF } \\
\text { RESPONDENTS }\end{array}$ & $\%$ \\
\hline GOLD & 310 & 62 \\
\hline PLATINUM & 25 & 5 \\
\hline SILVER & 40 & 8 \\
\hline DIAMOND & 125 & 25 \\
\hline TOTAL & 500 & 100 \\
\hline
\end{tabular}




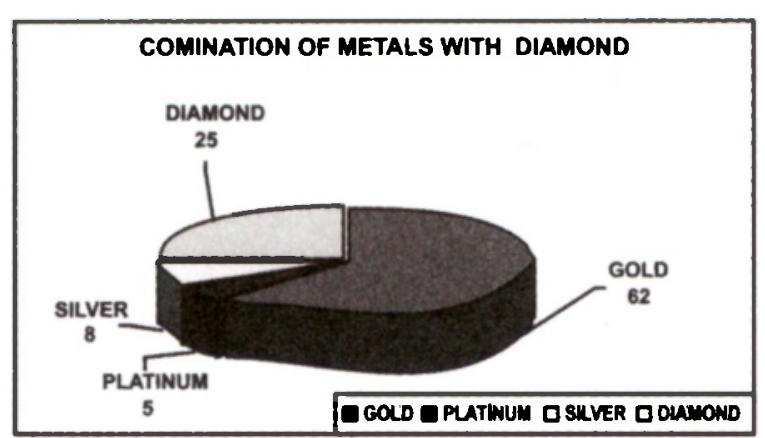

It is inferred from above table 10 that 310 respondents out of 500 preferred gold over other metals.

\section{Findings}

The findings of this research work can be listed as below:

1. Various factors like design, investment, etc. influence the purchasing decision of gold jewellery.

2. Emergence of new manufacturing techniques is influencing design patterns.

3. Technology has an important role with respect to retail gold jewellery trading viz., RFID, CCTV, CAM-manufacturing, Mediaadvertising online, phones etc.,

4. The latest developments are customers preference towards foreign designs, rising gold value, exhibitions, rising income level, there is increase in independence to purchase gold jewellery.

5. Business people invest more on gold as it is considered as reserve value.

6. Emergence of different materials - alloys within gold as well as non gold jewellery.

7. Newspapers still act as a major communication medium with respect to jewellery industry.

8. Gold is the most preferred metal.

\section{Observations}

- Goldsmiths 'losing out' to big jewellers in India

- Aggressive marketing campaigns by jewellery firms have promoted platinum, diamonds and other gem stones as these extra options mean that gold jewellery is suffering fewer sales.

- Man-made methods - machineries are competing highly with skills of goldsmiths.

- BIS - To facilitate transition, the Bureau of Indian Standards (BIS) has made hallmarking of jewellery compulsory from Jan 1, 2008

- Good Infrastructure with huge malls Branding the experience

- Retail Gold Jewellery Mantra - Target the young, Target Women

\section{Suggestion and Conciusion}

Retail Gold jewellery dealers have to focus on the technology, aggressive marketing aspects, brand equity, BIS standards, skilled goldsmiths and designers etc., It is for sure that retail gold market is going to take over effectively, as gold is an alltime high in India.

\section{REFERENCE}

- "Growing the Branded Jewellery Market : An Indian Experience ", The LBMA Precious Metals Conference 2004, Shanghai ( Paper presented by Harish Bhat Chief Operating Officer, Tanishq)

- "Fashions fade, Style is eternal", All that Glitters ( magazine), Volume 01, published on issue 03,2005 " Indian retail: on the fast track" , KPMG, Federation of Indian Chambers of Commerce and Industry, December 2005. 
- "Challenges and opportunities for gold retailing in India", by James Jose, MD, Chemmanur Gold

Refinery (P) Ltd., JCK 2006 AND JEWELS OF INDIA SPECIAL ISSUE magazine "The Art of Jewellery", VOL 05 ISSUE 09

- "In 2005 India contributed an estimated $14.3 \%$ of global jewellery production", ' Jewelbiz India ', Volume 03 published on March-April 2006

- "Gold Sales take a shine to Akshaya Tritiya" The Economic Times, 21 Apr 2007, V Hemamalini and Chandra R

- "Lighter gold jewellery popular with urban women", The Economic Times in India, Thursday 04th of January, 2007
- "Gold Showers a Celestial Blessings...", Vijaya Karnataka, 14 Apr 2007

- http://jewellery.indianetzone.com - "Branded Jewellery"

- "Be jeweled", Maulik Chandarana, Times of India 14 September 2009

- $\quad$ "Yellow Metal Rallies above Rs 16,200, may hurt demand", Times of India, September 2009

- $10^{\text {th }}$ Jewels of India, Excerpts from the interview with the convener, Mr. Sandeep Bekal 